\title{
EU developments and their impact on HR issues
}

Received: 22nd March, 2005

\section{Leonardo Sforza}

has been Head of Research and European Union Affairs at Hewitt Associates, a global HR outsourcing and consulting firm (HEW-NYSE), since 1999. Leonardo has 20 year's experience in EU law and assists the firm and Hewitt's global clients on the implications of EU policies for business, in particular in the fields of corporate governance, labour law and pensions. He is the Board's advisor of the European Club for Human Resources and collaborates regularly with other European think-tanks. $\mathrm{He}$ is a regular contributor to journals and speaker at international conferences in English, French and Italian.

Abstract Recent European Union (EU) developments will have an increasing impact on human resources policies and on corporate strategies related to people management. This paper looks at the most recent and future policy developments which are of greater interest to business leaders, human resources (HR) practitioners and their advisors, namely: pensions, people mobility and corporate governance. In particular, for each of these topics, the paper examines the rationale and the scope of the EU actions, together with the author's opinion about the likely impact of these measures on market and on the national regulatory frameworks.

Keywords: European Union; pan-European pension; human resource issues; corporate governance, labour mobility

\section{Should we care?}

The most common joke about European Union (EU) lawyers made by our colleagues practicing national law is that a question in Brussels is likely to get 26 different answers (the number of the national implementing rules in the member states plus one for the EU law itself) rather than just the one a client can get elsewhere. The first piece of bad news is that, as far as EU lawyers are concerned, this is true. The second piece of bad news concerns national Avenue des Cerisiers 15, bte 2,. Kerselarenaan 15 bus 2, 1030 Brussels, Belgium.

Tel: +3227438611 Fax: +3227438612 ; e-mail:

leonardo.sforza@ewitt.com practitioners who face possible multiple answers in order to cope with EU developments influencing local practices.

There are about 1,000 pages of EU law $^{1}$ and an endless list of judgments from the European Court of Justice (ECJ) dedicated to employment and labour-related issues. ${ }^{2}$ In addition, several initiatives taken in the context of corporate law, indirect taxation and financial service regulation often touch upon aspects which are relevant in people management practices and in the business-related sectors. Although in quantitative terms, this is still a small proportion of the overall legislative body built over the years at the EU level in a wide range of domains, the nature and the scope of these measures are such that they have a crucial impact on human resources (HR) policies, on corporate strategies and on service providers. Despite the increasing fears for over-regulation and interference from 'Brussels', six out of ten Europeans positively evaluate EU membership ${ }^{3}$ and the list of candidate countries wishing to join the EU has almost doubled in a decade. Today's geographic scope of the 
EU legal framework reaches 25 sovereign states, 450 million people and 25 million enterprises, 8,000 of which are publicly traded. Bulgaria and Romania will come next in 2007; while later on, the time may come for Croatia and Turkey.

Beyond membership, the bilateral agreement in place between the EU and more than 100 countries offers a further framework of cooperation and cross-border governance which often involves a regulatory dimension relevant to business.

Irrespective of the different political opinions we may have for, or against, the EU, about its final objectives, real achievements and means, the EU plays such a role in our everyday life, and on the world scene, that the only way to circumvent it would be by burying our heads in the sand. A close look at the most recent and future policy developments which are of greater interest to business leaders and HR practitioners show that there are three policy areas which have been taking a priority on the EU agenda. These are: pensions, people mobility and corporate governance. Only a few years ago, these same topics were a taboo even for informal conversation at a relaxed EU lunch. This paper offers an overview of the rationale beyond the EU initiatives, of their nature and legal scope, together with the author's own opinion on the likely impact that they will have on the market and on the national regulatory frameworks.

\section{Single market for private pensions under construction}

Demographic changes, labour market conditions, public debt control and, not least, the lack of progress in the single market for financial services are the main factors which have imposed pensions on the EU agenda and brought higher pressure for reform at national and European levels. A brief reminder of new facts and figures confirms that the case for action is both urgent and critical for the European economy and its social model.

First, the combination of increasing life expectancy and falling fertility rates will reduce the European working age population by 21 million people, and will increase, by 40 million, the number of people of 65 years or more by the year $2030 .^{4}$ In parallel, despite the fact that the average life expectancy has risen to 65 years for women and 64 years for men over the last 40 decades, the effective age of retirement has almost remained the same.

Secondly, the generous pre-retirement welfare programmes and the tax-wedge on working-related benefits in most continental European countries have been clear disincentives for the older workers to remain active. In addition, the smaller employment rate of women compared to men in the same countries, has made even more evident the case of untapped human resources in support of the welfare system and more generally of the economy. ${ }^{5}$ At the end without reform, the proportion of people in employment - those who finance the state pension benefits of retirees versus the non-working age population, risks being cut down by half, by $2030 .{ }^{6}$

Thirdly, the impact that the current system has on public finance and on macro-economic stability. It explains why Ministers of Finance were the first to push the talk about pensions to EU level. The burden in terms of additional financial resources needed to finance the 'pay as you go' system of pensions has been estimated to range between three and eight per cent of GDP, depending on the individual country.

Finally, the recognition of the need to remove the numerous legal obstacles 
hindering the single market of financial services, including private pensions, and undermining the quality and liquidity of the European capital market. The establishment of a 'single market' without frontiers - where people, goods, capital and services can freely circulate - is the main plank of the EU project, and is probably its most attractive promise. In this area, contrary to the issues raised above where member states keep full exclusive competences for action and the EU has only a monitoring role with the possibility to address recommendations, the EU is empowered to legislate and can even take action against member states for practices infringing the single market principles. In the area of occupational pensions, ten years after the launch of the single market implementation process, we have finally taken two important steps forward. The business pressure, the willingness of influential policy makers in Parliament, but also the courage and determination of both the European Commission (EC) and the ECJ have led, in a relatively short period of time compared to the usual 'biblical' standards of the EU, to:

(a) the adoption of a pan-European legal regime for the establishment and management of pension funds; ${ }^{8}$

(b) The recognition as unlawful of several cases of national law which discriminate for tax purposes the deductibility of contributions paid to foreign based pension funds. ${ }^{9}$

In the case of the Pension Fund Directive, the adoption of the Directive by the EU decision-makers is the beginning, rather than the end, of the story, because a further transposition into the national legislation of each member state is required. In this context the grace ends on 23rd September, 2005. Some countries such as the Netherlands,
Ireland, Luxembourg and the UK are well advanced in the transposition process and have lot to gain if they choose the path of a simplified regulatory environment. By doing so they could make the country an attractive location for the 'EU model' funds. Other countries, as usual, will wait until the 'last minute' if not longer, unless they are confronted with EC legal and business community pressure for compliance. On several occasions in the past we have pleaded for a more pro-active approach by the EC in supporting, accompanying and 'coaching' the national administrations during the transition period rather than pursuing the country at a later stage for an incorrect transposition of EU law. This avoids further delay, reduces the risk of legal uncertainty and ensures greater coherence and consistency throughout Europe of the principles stated in the relevant Directive. It seems that the message has been heard for pensions: two working groups are now in place. These involve national experts and national supervisory authorities that are trying to reach a common understanding of the many grey areas left open by the Directive.

Moreover, the commitment taken by the new Commissioner in office, Charlie McCreevey, towards a greater focus during his mandate on the effective implementation of existing single market rules, rather than on the addition of new ones, should allow - or where necessary force - national administrations to work in the right direction.

In the case of taxation, although it is much harder to win national sensitivity - especially when tax-related earnings and short-term national interests would be affected - we can already see the signs of change and a new sense of speed for change is winning at least some of the countries that have infringed the EU law. Each member state will continue to 
keep full power in determining its own conditions for the taxation of pensions, but this tax treatment must remain neutral when applied to cross-border arrangements.

In a nutshell, thanks to these developments, companies will have the opportunity:

(a) to set up their pension fund in any EU country irrespective of the locations of the sponsor, of the members/beneficiaries and of the service providers;

(b) to make cross-border affiliation under a unique fund, irrespective of the location of the employees;

(c) to define their own investment policy in accordance with the prudent person principle, while protecting the interests of fund members and beneficiaries;

(d) to deduct for tax purposes the contributions paid to a foreign-based fund without difference of treatment compared to the sponsorship of a local-based fund.

The complexity of the EU decision-making process, the hectic paths it often takes and the lack of plain communication from the institutions and the national public authorities do not help business leaders or the citizens who are potential beneficiaries of these measures, to be confident and gain a thorough understanding of what that means for them. Professional associations, service providers and corporate advisors have a greater role to play in this respect.

\section{Enhancing cross-border employees' mobility}

The need to improve processes and reduce costs, while at the same time continuing to invest in research, innovation, talent attraction and staff development are among the main challenges that companies are facing to succeed in today's highly competitive environment. Global sourcing, employee mobility and a more efficient management of work allocation and talent are among the management solutions identified by businesses. Innovative companies - those relying heavily on $\mathrm{R} \& \mathrm{D}$ for their success, those operating across borders and those willing to enter new markets or experiencing double-digit growth - have designed staff mobility policies and practices that aim to better fulfil both business needs and employee satisfaction. Until now, the regulatory environment has not been supportive of these business needs. ${ }^{10}$ Two more recent EU initiatives are likely to impress a change of direction on this front.

January 2005 saw the launch, of an unconventional debate about the terms and conditions for an EU approach to managing economic migration of third-country nationals from outside the EU. ${ }^{11}$ The growth of the EU's population has been substantially driven by migratory flows from non-EU countries into the region. Although migration-friendly policies alone cannot solve the economic problems derived from the ageing of the EU working population, they can reduce its negative impact. These flows have already helped to close local employment gaps in labour market supply, especially for job positions requiring very high or very low skills. In both cases, meeting labour market demand through immigration has not competed in general, nor overlapped, with local unemployment. Nevertheless, the positive economic impact of migratory flows on the country of destination is not always acknowledged in public opinion or in the policy measures taken by national authorities in 
this area. At present, an economic migrant from outside the EU faces 25 different sets of rules. It would be in the interests of both migrants and EU member states to have a common set of basic procedures, definitions and criteria that could lead to a sort of 'green card' as operated in USA. These would complement national admission systems and member states would remain fully in control of determining the numbers of economic migrants they admit.

Secondly, the removal of existing administrative barriers to intra-EU mobility. ${ }^{12}$ One of the apparent paradoxes that Europe is confronted with is the existence of a high unemployment rate - on average more than twice the US rate - and a very low rate of cross-border geographic mobility - six times less important than in the USA within the EU single market.

The range of practices and the motivations behind a company's decision to post an employee abroad have been widening in recent years. Similarly, employees' opportunities to work abroad have also expanded. Mobility policies will continue to grow in parallel with the increased globalisation of the markets and regional integration. Today's company recruitment and mobility policies in the EU often integrate the single market and single currency logic, but they continue to be confronted with a legal and administrative environment that remains costly and hostile to mobility. Companies are taking care of the direct and indirect additional costs related to employee mobility. The on-going implementation of the EU Directive aiming to safeguard the supplementary pension rights of employed and self-employed persons moving from one country to another constitutes an important step on removing obstacles to free movement relating to supplementary pensions. ${ }^{13}$ The
Directive does not, however, cover, the so called 'portability' rights (ie the possibility to transfer acquired pension rights to a new scheme in the event of professional mobility). The Commission is currently working on a controversial legislative proposal aiming to establish common minimum requirements, including the reduction of 'vesting' periods to claim acquired pension rights, and improve the portability of occupational pension schemes. The proposal is being opposed by the largest European business organisation (UNICE) because it would impose more constraints on business, leading to higher costs.

\section{Towards a European framework for corporate governance}

EC activity in this area has been driven by the need to restore confidence in corporate Europe and in the securities market after the waves of financial scandals in Europe and the USA. By way of 'recommendations', the EC has started to concentrate on two of the areas it considers most problematic from a corporate governance perspective, namely: the transparency of directors' remuneration, and the role of independent non-executive board members of listed companies in Europe.

The first recommendation ${ }^{14}$ details the principles and practices to be followed when designing directors' remuneration packages while, at the same time, enhancing shareholder control over pay decisions. The second recommendation ${ }^{15}$ defines minimum standards for the creation, composition and role of the nomination, remuneration and audit committees. The EC considers these related functions to be at high risk for potential conflicts of interest.

Recommendations are, by nature, not binding and are formally addressed to 
member states, which leaves companies free to endorse or ignore them.

Nonetheless, this EU move will continue to lead to tougher statutory requirements for public company direction, management and control of operations. In some member states, the orientation underpinning the EC's recommendations is already part of the regulatory regime; however, in most continental European countries, the transparency of board members' pay and related policies remain controversial issues. The practical implementation of the two recommendations is now in the hands of the 25 EU member states. After June 2006, if the Commission is not satisfied with progress made on this front, it could create further measures that are likely to become mandatory.

HR managers and executives are often called to assist the board in designing and implementing policies and processes in the areas of remuneration, performance evaluation, and leadership development. With the progressive development of stricter corporate governance guidelines, these professionals will play an even more crucial role by mastering and integrating corporate governance principles and practices throughout the organisation.

\section{Conclusion}

The EU institutions are more than ever at a crossroads. Business leaders and, what is called the 'civil society' have increasing legitimate expectations on 'what' and 'how' the EU should deliver on many aspects of their daily operations. Irrespective of the national specific priorities of what the EU policy agenda should be, a general consensus is emerging for a 'lighter' but more effective EU activity, for less red tape and more economic growth-driven actions. There are still some contradictory signals coming from the new European Commission and European Parliament, about their capacity to focus on structural reform and better rule-making. The compelling debate being opened around the new constitutional treaty in several member states will eventually force the EU institutions to greater accountability vis-á-vis business and people needs.

Above all, the Commission should focus more and better on the quality and coherence of the implementation by the member states of the EU law already adopted. The uncertainty and opacity of the transposition of the EU rules substantially undermine our capacity to benefit from the single market and, even worse, create an anti-competitive environment which rewards the failures and punish those that comply. Finally, the trans-regional dimension can no longer be underestimated or confined to a 'nice to have' conference topic. Our companies operate and compete on the world scene, the dialogue and cooperation with the US regulatory authorities, but also with the authorities of the most dynamic economies such as India and China, should be fostered with a view to making a new qualitative leap which reflects the new business world.

\section{References}

1 The updated list and the specific texts of the EU legislation related to employment are available online at: www.europa.cu.int/eur-lex/lex/en/repert/ index_05.htm.

2 All the case law of the European Court of Justice is accessible at: www.curia.eu.int/index.htm.

3 According to the results of the last pan-European public opinion poll Eurobarometer 62, a survey coordinated by Taylor Nelson and EOS Gallup Europe in November 2004 on behalf of the European Commission.

4 From 2030, Europe's population is set to decline in all member states, the only exceptions being France and the UK. In contrast, US population will rise by 25.6 per cent within the next 20 years. This is the forecast elaboration of a base-line scenario carricd out by Eurostat for EU 25, in: European 
Commission, 'Europe's changing population structure and its impact on relations between the generations', Memo/05/96 of 17th March, 2005.

5 The lower employment rate of EU countries compared to the USA is at the origin of the productivity gap between the two regions and one of the main reasons of the lower growth rate of the economy on this side of the Atlantic. For a comparative analysis on employment rate and productivity gap see the European Commission staff working paper 'Second implementation report on the 2003-2005 Broad Economic policy guidelines', SEC(2005) 91 of 27 th January, 2005

6 For a detailed analysis of the evolution of the dependency ratio and demographic challenges, see the European Commission Green Paper 'Confronting demographic change: a new solidarity between generations', COM(2005) 94 final of 16 th March, 2005.

7 For a thorough analysis of the impact of pensions on public deficit in Europe, see the 'European Economy' report series at www.europa.int.eu.

8 Directive 2003/41/EC of the European Parliament and of the Council on the activities and supervision of institutions for occupational retirement provisions. Published in the Official Journal of the EC, L235, 23rd September, 2003. For a more detailed analysis of the Directive and of the complementary measures taken on taxation of pensions from a corporate perspective see Reay, T. and Sforza, L. (2004) 'Developments in European pensions - What does all this mean for employers?' in Benefit $\mathcal{E}$ Compensation Imtermational, Vol. 33, No. 9, p. 3. And also Phillips Taft, F. (2005) 'Developing a single market for occupational pension in Europe - The IORPs Directive', Business Law Intemational, Vol. 6 No. 1, p. 21

9 For a more detailed analysis of the Directive and of the complementary measures taken on taxation of pension from a corporate perspective see above. See also Murray, J. (2004) 'The European Approach to pensions and its impact on small self-administered schemes' in Pensions, Vol. 10, No. 1, p. 57.

10 For an analysis of socio-economic trends and business policies related to employee mobility, see the report of the CEPS-ECHR Taskforce. 'A new European agenda for labour mobility', Center for European Policy Studies and European Club for Human Resources, Brussels, 2004.

11 European Commission, Green paper on 'An EU Approach to Managing Economic Migration', 11th January, 2005.

12 The detailed list of legislative and other actions undertaken by the EU in support of intra-EU people mobility is available online at: www.europa.eu.int/comm/employment_social/free_ movement/index_en.htm.

13 Directive 98/49 EC in Official Journal No. L 209 of 25th July, 1998.

14 Commission Recommendation of 14th December, 2004 on 'Fostering an appropriate regime for the remuneration of directors of listed companies', in Official Journal No. L385, 29th December, 2004.

15 Commission Recommendation of 15 th February, 2005 on the role of non-executive or supervisory directors of listed companies and on the committees of the (supervisory) board', in Official Joumal No. L52, 25th February, 2005 